Article

\title{
The Ethico-Political Theory of Thomas Aquinas and the Revival of Capital Punishment in the Philippines
}

Jovito V. Cariño

\begin{abstract}
In key passages of Summa Theologiae, specifically under the questions on tolerance of heretics (IIaIIae.11.3) and killing of sinners (IIaIIae.64.2), Thomas Aquinas considers the acceptability of death as penalty for a person who endangers either faith or well-being of a community. If one considers the testimony of these texts alone, it would appear as if capital punishment has found a champion in no less than the premier Catholic philosopher himself. There are in fact those who seriously look up to Aquinas as a death penalty advocate. While his insights on capital punishment are crucial, one wonders however whether appeal to the aforementioned texts in question can do justice to the inherent complexity of Thomistic ethico-political theory and to the question itself of capital punishment. How then does one weigh Aquinas' opinion on the possibility of capital punishment against his sustained and affirmative commitment to the fullness of human life, be it in the context of an individual or a community? This paper intends to address this apparent tension within Thomas Aquinas' ethicopolitical theory vis-à-vis the current debate on the re-imposition of capital punishment in the Philippines, a predominantly Catholic country. As important, therefore, as making a Catholic rejoinder in this exchange is the effort to understand better the mind of Aquinas on the said issue. Through such undertaking, one acquires an opportunity to guarantee Catholic presence in the public debate while highlighting at the same time the continuing relevance of Thomistic theory on the pressing ethical and political issues of the day.
\end{abstract}

Keywords: ethico-political theory, capital punishment, Catholic, Philippines 


\section{AQUINAS AND CAPITAL PUNISHMENT IN THE PHILIPPINES}

\section{Introduction}

7 his paper is conceived mainly as a counterpoint to certain perspectives which put Thomas Aquinas on the affirmative side on the question of whether or not capital punishment should be reinstated in the Philippine legal system. This suggestion is apparently informed by certain texts from Summa Theologiae where Aquinas justifies the imposition of capital punishment on specific cases like murder and heresy. Proponents of this suggestion likewise maintain that the Catholic faithful ought not to oppose capital punishment on the strength of Aquinas' favorable remarks. This paper argues that Aquinas' position on this matter is much more nuanced than what is supposed by the specific extracts from the Summa; hence, advocates of capital punishment, Catholics or not, should take Aquinas' words with maximum care before invoking his authority to argue for an otherwise contentious claim. I will demonstrate that the complexity of Aquinas' issues from an apparent tension between his theological opinion on situations where capital punishment is suggested as a penalty and his political theory which contextualizes the enactment of a law like capital punishment is rather disputable. In considering, therefore, a piece of a proposed legislation of which capital punishment is an example, I maintain that political theory should take precedence over a theological claim, owing to the former's more fundamental relevance on the issue at hand. I will try to develop this argument in five parts. First, I will make an account of the context that purports to justify the revival of capital punishment in the Philippines. To examine the conjunction of this proposal with Aquinas' mind, I shall turn, in the second part, to his position on capital punishment as articulated in Summa Theologiae, in particular, QQ 11 and 64. Consistent with my argument, I will discuss in the third part a perceived tension in Aquinas' position on the capital punishment by fleshing out two important distinctions, to wit, the distinction between a) capital punishment as a subject of theological opinion; and b) capital punishment as a subject of legislation. In the fifth and concluding part, I will further underscore my claim that a reductive reading of Thomas Aquinas to argue for the re-imposition of capital punishment in the Philippines will not help its cause. Besides the flimsy appeal to authority frowned upon by Aquinas himself, such approach betrays the complexity of Aquinas' insights as well as the problems inherent in the very idea of capital punishment.

\section{A Culture of Death}

As early as the 2016 electoral campaign period, the erstwhile presidential candidate Rodrigo Duterte, had been very vocal about his 
dogged obsession to curb the problem of criminality in the country and had, in fact, dared the public to get himself killed, ${ }^{1}$ should he win but fail to wipe out criminals across the archipelago six months after taking office. ${ }^{2}$ Close to a year later, the Philippine National Police reported that crime rate has significantly dropped indeed by $31 \%$ under the Durterte administration. This means that 81,064 crime incidents recorded from July to November 2015 substantially dipped to 55,391 within the same period for the year 2016. ${ }^{3}$ This is, no doubt, a remarkable feat and one that should give all citizens a good reason to feel relieved. But remarkable as it may seem, there is yet another side to the fight against crime-a side that one needs to take into account if these reported gains must be appreciated for what they are worth. It should be remembered that in the same duration, from July to November 2016, a record of more than 4,000 deaths was reported in the name of the so-called "war on drugs." ${ }^{4}$ This staggering number of killings in such a short period of time readily overshadows the record of reported 3,257 deaths throughout the more than two-decade rule of Marcos. ${ }^{5}$ Duterte is wont to consider illegal drugs as the root of all crimes, and hence, the relentless, vociferous campaign to bring its menace to an end regardless of the means employed and the consequences involved. ${ }^{6}$ To underscore his resolve, he even made a remark as to how willing he was to exterminate everyone who was hooked on illegal

${ }^{1}$ See Aries Joseph Hegina "Duterte: Kill me if I fail to bust crime, corruption in 6 months, in Inquirer.net (17 January 2016), <http://newsinfo.inquirer.net/756194/duterte-kill-meif-i-fail-to-bust-crime-corruption-in-6-months $>, 5$ October 2017.

${ }^{2} \mathrm{Mr}$. Duterte has since backtracked on this pronouncement and has since asked for an extended time to clean the country of criminality. Nestor Corrales "Duterte wants war on crime, drugs extended for 6 more months," in Inquirer.net (18 September 2016), $<\underline{\text { http://newsinfo.inquirer.net/816443/duterte-asks-for-another-6-months-to-stop-crime-drugs }>\text {, }}$ 5 October 2017.

${ }^{3}$ See CNN Philippines Staff, "Overall crime rate falls in the first five months of Duterte presidency," in CNN Philippines (21 December 2016), $<$ http://cnnphilippines.com/news/2016/12/20/Overall-crime-rate-falls-in-first-five-months-ofDuterte-presidency.html $>, 5$ October 2017.

4 See "Philippines: Events of 2016," in Human Rights Watch, $<$ https://www.hrw.org/world-report/2017/country-chapters/philippines\#1ff4dc $>, \quad 5$ October 2017.

${ }^{5}$ See Rishi Iyengar, "The Killing Time: Inside Philippine President Rodrigo Duterte's War on Drugs," in Time (25 August 2016), <http://time.com/4462352/rodrigo-duterte-drug-wardrugs-philippines-killing/>, 5 October 2017.

${ }^{6}$ In his 2017 State of the Nation Address, for example, Duterte once more reiterated his conviction concerning the omni-malevolent role of illegal drugs. As he stressed: "That is why, I have resolved that no matter how long it takes, the fight against illegal drugs will continue because that is the root cause of so much evil and so much suffering that weakens the social fabric and deters foreign investments from pouring in. The fight will be unremitting as it will be unrelenting." For a transcript of his speech, see: Rodrigo Duterte, State of the Nation Address, 24 July 2017, in Rappler (25 July 2017), <https://www.rappler.com/nation/176566-full-text-presidentrodrigo-duterte-sona-2017-philippines $>, 6$ October 2017. 


\section{AQUINAS AND CAPITAL PUNISHMENT IN THE PHILIPPINES}

drugs numbering to almost three million. ${ }^{7}$ By issuing pronouncements of this kind, Duterte, his critics charged, makes it appear as though the summary execution of drug personalities is a legitimate state function. The spate, therefore, of killings is seen by them as a direct consequence of Duterte's explicit encouragement of the so called "extra-judicial killing." In its "Annual Report on Human Rights Defenders at Risk in 2016," the human rights watchdog, Front Line Defenders, asserts: "In the Philippines-which already ranks as the most dangerous country in Asia for [human rights defenders]President Rodrigo Duterte normalized the act of extrajudicial killing in his war on drugs, lowering the political cost of murder and thus raising the risk to defenders whose work threatens powerful interests," 8 To paraphrase Marx, a spectre haunts the Philippines; and this spectre is, as observers describe it, a creeping "culture of death." 9

Rather than acting to curb the increasing number of drug-related killings, the Duterte administration decides instead to introduce a bill seeking to legalize death as a means to penalize drug-related crimes. What makes the whole suggestion scandalous is the very thought of an official endorsement of death as a state policy. There is indeed something thoroughly disquieting when the state becomes the prime agent to legitimize the extant barbarism still in force in the legal infrastructure of capital punishment. The essential inhumanity characteristic of this extreme penalty is not unknown to the Philippines as attested by its abrogation of capital punishment in 2006 via Republic Act $9346^{10}$ and its ratification in 2007 of an international anti-death penalty treaty called the Second Optional Protocol to the International Covenant on Civil and Political Rights. ${ }^{11}$ These are the gains that the proposed legislative measure called House Bill 4727 are set to overturn if indeed its proponents will have their way. House Bill 4727 is a legislative

\footnotetext{
7 See "Duterte says he's 'happy' to eliminate drug addicts," in Philstar.com (30 September 2016), <https://www.philstar.com/other-sections/news-videos/2016/09/ 30/1629004/watch-duterte-says-hes-happy-eliminate-drug-addicts $>, 6$ October 2017.

${ }^{8}$ See Jee Y. Geronimo, "Duterte 'normalized act of extrajudicial killing," in Rappler (06 January 2017), <https://www.rappler.com/nation/157528-duterte-extrajudicial-killing-humanrights $>6$, October 2017.

${ }^{9}$ See Ellen T. Tordesillas, "Opinion: Culture of death under Duterte presidency," in ABS-CBN News (04 March 2017), <http://news.abscbn.com/blogs/opinions/03/03/17/opinionculture-of-death-under-duterte-presidency>, 6 October 2017. For a parallel perspective, see also David Garland, David, The Culture of Control: Crime and Social Order in Contemporary Society (Chicago: The University of Chicago Press, 2002), 139-165.

${ }^{10}$ Republic Act No. 9346: "An Act Prohibiting the Imposition of Death Penalty in the Philippines" (2006).

${ }^{11}$ Second Optional Protocol to the International Covenant on Civil and Political Rights, aiming at the abolition of death penalty, United Nations Treaty Series, vol. 1642 (15 December 1989), <https://treaties.un.org/Pages/ViewDetails.aspx?src=IND\&mtdsg no=IV-12\&chapter=4\& clang=_en>.

(c) 2018 Jovito V. Cariño

https://www.kritike.org/journal/issue 22/carino1 june2018.pdf

ISSN 1908-7330
}

(cc) BY-NC-ND 
vehicle envisioned to restore capital punishment in the Philippine penal system. It specifically targets drug-related crimes but excludes such graver offenses like kidnap-for-ransom, plunder, and rape. As it is, the instrumentalization of death invites serious objection especially when more and more of its victims turn out to be the very citizens who look up to the state for protection and defense. ${ }^{12}$ A necessary distinction, therefore, has to be made between legitimizing death as a form of penalty and justifying penalty which may at times require capital punishment. The former reminds us of Michel Foucault's notion of biopower, a term he used to describe the extent of the modern state's proclivity to subject to its own political machinations the life processes, including the death of its own citizens, so as to fortify its hegemony as the lone sovereign. ${ }^{13}$ The latter however points us to Thomas Aquinas for whom care of the community is the preeminent task of a public person occupying a position of power. ${ }^{14}$ At this point, someone may advance an argument and point out that the proposed revival of capital punishment in the Philippines intends nothing but the common good, and, on such ground, should be seen as consistent with Thomistic ethico-political thought. In the ensuing part of this paper, I will try to problematize this claim and put forward a position that will show how the aforementioned argument has no immediate warrant within Aquinas' ethico-political framework. I maintain that Aquinas' take on capital punishment is more nuanced than it appears and should, therefore, be read with caution lest his philosophy is misused to

\footnotetext{
${ }^{12}$ See "'License to Kill': Philippine Police Killings in Duterte's 'War on Drugs,'” in Human Rights Watch (March 2017), <https://www.hrw.org/sites/default/files/report pdf/ philippines0317_insert.pdf $>$, 5 June 2018.
}

${ }^{13}$ The example cited by Foucault to drive home his point was the Nazi regime. As explained by Foucault: "We have, then, in Nazi society something that is really quite extraordinary: this is a society which has generalized biopower in an absolute sense, but which has also generalized the sovereign right to kill. The two mechanisms-the classic, archaic mechanism that gave the State the right of life and death over its citizens, and the new mechanism organized around discipline and regulation, or in other words, the new mechanisms of biopower, coincide exactly. The Nazi state makes the field of the life it manages, protects, guarantees, and cultivates in biological terms absolutely coextensive with the sovereign right to kill anyone, meaning not only other people but also its own people. There was, in Nazism, a coincidence between a generalized biopower and a dictatorship that was at once absolute and retransmitted throughout the entire social body by this fantastic extension of the right to kill and of exposure to death." Michel Foucault, "Society Must be Defended": Lectures at the College de France, ed. by Mauro Bertani and Alessandro Fontana, trans. by David Macey (New York: Picador, 2004), 260.

${ }^{14}$ Aquinas wrote: "From this it is clearly shown that the idea of king implies that he be one man who is chief and that he be a shepherd, seeking the common good of the multitude and not his own." Thomas Aquinas, De Regno ad regem Cypri [On Kingship: To the King of Cyprus], trans. by Gerald B. Phelan, rev. by I. Th. Eschmann, ed. by Joseph Kenny (Torono: The Pontifical Institute of the Mediaeval Studies, 1949), in St. Thomas' Works in English, comp, by Joseph Kenny, in Dominican House of Studies: Priory of the Immaculate Conception, $<$ http://dhspriory.org/thomas/DeRegno.htm $>, 7$ October 2013, 2.13. 


\section{AQUINAS AND CAPITAL PUNISHMENT IN THE PHILIPPINES}

compensate for the rational deficit that is at the core of the very notion of the proposed revival of capital punishment in the Philippines.

\section{Aquinas and Capital Punishment}

It should be stated, at the outset, that Aquinas' ethico-political theory is framed within the larger structure of his theological system. Therefore, unlike other theories on ethics and politics, what he has to say on any ethical or political issue like capital punishment is heavily invested in his fundamental creedal commitment. In Summa Contra Gentiles, for example, Aquinas invokes "the office of the wise man" whose main concern should be none other than "the highest causes"-his philosophical reference for everything under the umbrella of his primary theological interests. ${ }^{15}$ This foundational theological slant explains why one would hardly find a standalone ethico-political treatise in Aquinas' oeuvre. Among his works, other than the ethico-political discourses found in Summa Theologiae (like the questions on justice, virtues, law, among others), the only materials with considerable explicit ethical and political orientation are On Kingship (1267), the commentaries on Aristotle's Nicomachean Ethics (1271-72) and Politics (1269-72), and Disputed Questions on Virtues (1271-72). This peculiarity notwithstanding, there is no way the said materials can be detached from the theological bent of Aquinas' intellectual system. The recognition of this basic fact, therefore, is indispensable in appreciating the full import of Thomistic ethico-political theory, particularly his position on the imposition of capital punishment.

The question of whether or not capital punishment should be enforced is addressed by Aquinas three times in Summa Theologica: twice in Question 64, specifically in articles 2 and 3, and once in Question 11, specifically in article 3 .

Aquinas discusses the issue of murder in Question 64. In the second article of the same topic, he grapples with the problem of the legality of killing sinners. From his conviction that an individual is but a part of the whole, he opines that the life of such individual may be sacrificed if he has become a threat to the welfare of the community. He explains that "... every individual person is compared to the whole community, as part to whole. Therefore if a man be dangerous and infectious to the community, on account of some sin, it is praiseworthy and advantageous that he be killed in

15 Thomas Aquinas, Summa Contra Gentiles, trans. by Anton C. Pegis, James F. Anderson, Vernon J. Bourke, and Charles J. O'Neil, ed. by Joseph Kenny (New York: Hannover House, 1955-57) in St. Thomas' Works in English, comp. by Joseph Kenny, in Dominican House of Studies: Priory of the Immaculate Conception, $<$ http://dhspriory.org/thomas/ContraGentiles.htm>, 7 October 2017, 1.1.

(c) 2018 Jovito V. Cariño

https://www.kritike.org/journal/issue 22/carino1 june2018.pdf

ISSN 1908-7330

$((c))$ BY-NC-ND 
order to safeguard the common good, since 'a little leaven corrupteth the whole lump' (1 Corinthians 5:6)."16

In the following article of the same question, Aquinas tries to settle the issue of whether such killing should be undertaken by an individual or by a public person. Since the task of promoting common good is incumbent upon the public person, it is then to him alone and not to a private citizen that the determination of such killing belongs. ${ }^{17}$

The third instance where Aquinas confronts the question of capital punishment is found in article 3 of Question 11, that is, on the question of whether or not heretics should be tolerated. Aquinas' answer is just as stern. Heretics should be deprived of life since their sin, that is, corruption of faith, is a much graver error compared to the infractions of other depraved individuals. ${ }^{18}$

In all three situations, Aquinas registers a positive stance on the question of capital punishment. Moreover, in all three of them, he justifies his position by appealing to the inviolability of common good. To his mind, it is common good alone that could serve as a sufficient ground for the sacrifice of the life of an individual. To the question then whether Aquinas is supportive of capital punishment, one may confidently answer in the affirmative. The situation, however, may turn around if one asks whether Aquinas' arguments as developed in Summa Theologiae can be used to justify the proposed revival of capital punishment in the Philippines. The distinction between these two questions is as much a matter of content as its theoretical framework. Whereas in the Summa, Aquinas is articulating a theological opinion on idealized situations that would warrant capital punishment, in the Philippines, what is at issue is the lack of substantive arguments that could lend capital punishment sufficient moral and legal gravitas. In other words, Aquinas can afford to extrapolate on the possibility of enforcing capital punishment on account of a tacit proviso that the rational and legal infrastructure for such is already in place. In the Philippine case, capital punishment is a contentious issue because the proposal to revive it tends to contradict the very rational and legal infrastructure which serves as its normative context. When I proceed, then, to the next segment of this paper, I shall offer two important distinctions in support of my claim that Aquinas' arguments and the Philippine proposal to revive capital punishment cannot be reconciled.

16 Thomas Aquinas, Summa Theologiae, trans. by Fathers of the English Dominican Province, $2^{\text {nd }}$ and rev. ed. (London: Burns Oates \& Washbourne, Ltd., 1920), in New Advent,

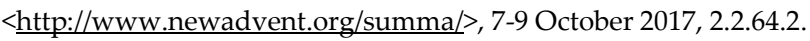

${ }^{17}$ Ibid., 2.2.64.3.

${ }^{18}$ Ibid., 2.2.11.3.

(C) 2018 Jovito V. Cariño

https://www.kritike.org/journal/issue 22/carino1 june2018.pdf

ISSN 1908-7330 


\section{AQUINAS AND CAPITAL PUNISHMENT IN THE PHILIPPINES}

\section{Important Nuances to Consider: Theology and Legal Theory}

As suggested in the preceding paragraphs, Aquinas' position on capital punishment, though affirmative, cannot be taken at its face value as an outright endorsement of death penalty without further consideration. My task in the segment at hand is to deliberate cautiously on the salient nuances of Thomist ethico-political theories vis-à-vis the question of capital punishment and, in so doing, bolster further my claim that the proposed reimposition of capital punishment derives a very thin theoretical support from the philosophy of Thomas Aquinas. I shall make an account of this argument by clarifying the distinction between a) capital punishment as a subject of theological opinion; and b) capital punishment as a subject of legislation.

a) Capital punishment as a subject of theological opinion. To consider capital punishment as a subject of theological opinion is to acknowledge its theological character in Aquinas' discourse. This has been established as a matter of fact having identified Summa Theologiae as the main locus of Aquinas' discussion of the said problem. The three instances where this question was properly addressed in the Summa had been identified in the preceding paragraphs. What is notable in all three references is Aquinas' attempt to link capital punishment with his sustained discussion of sin. As it is, sin is a theological concept and Aquinas defines it as "contrary to virtue" and "an inordinate act." 19 In the passages cited above, Aquinas relates sin with common good. He considers the specific inordinate acts of murder and heresy as injurious to common good and the person or persons who do them become major threats to such. Being so, Aquinas recommends that they be put to death so as to keep the good of the community intact. He reasons that an individual is related to the community as part is to the whole. When a part therefore endangers the well-being of the whole, it becomes necessary and justified for his life to be taken out for the greater good of the community. In maintaining this, is Aquinas then making an outright endorsement of capital punishment?

This seems to be the suggestion of Summa Theologiae at first glance, and one that warrants serious consideration if its bearing on the revival of capital punishment in the Philippines should be clearly understood.

This is not, of course, the first time that the name of Aquinas is dragged into the issue of capital punishment. Shadia Drury, author of Terror and Civilization: Christianity, Poltics and The Western Psyche for example, deplored Aquinas' complicity with the hostility of the Catholic Church against heretics. ${ }^{20}$ In another work, Drury dished out yet another stinging

${ }^{19}$ Ibid., 2.1.71.4.

${ }^{20}$ Shadia Drury, Terror and Civilization: Christianity, Politics and the Western Psyche (New York: Palgrave MacMillan, 2004), 11.

(c) 2018 Jovito V. Cariño

https://www.kritike.org/journal/issue 22/carino1 june2018.pdf

ISSN 1908-7330

(cc) BY-NC-ND 
remark directed at Aquinas against the contrary claims of an eminent Thomist Jesuit scholar, Josef Pieper. In Aquinas and Modernity: The Lost Promise of Natural Law, Drury asserted that "... Aquinas did not make a single critical remark about the activities of his fellow Domini Canes, even though he was fully cognizant of their conduct. Aquinas's analogy of heresy with communicable disease ensured that a presumption of guilt was inevitable and that killing a few innocent people was preferable to allowing a single heretic to go free." 21 Judging from these works including an article published online in New Humanist, ${ }^{22}$ Drury obviously harbored very little affection for Aquinas. Her conclusions, nonetheless, are exactly the standard account that one would gather if Aquinas were judged solely on the testimony of his unsympathetic statements against the heretics who, during the medieval ages, were the sworn enemies of the Catholic Church. As a friar preacher and a professional theologian, his pronouncements on the death warrant for heretics could, at the most, be considered as a polemical stance on the thorny issue of heresy. As they are, they may serve as an insufficient basis for a balanced interpretation of Aquinas' mind on the matter. It is likewise important to note that heresy was considered a widespread socio-political malaise which threatened ecclesiastical and secular institutions across Jewish, Christian, and Islamic religions alike during the medieval ages. Emperor Frederick II himself, for example, for all his inimical posturing against the Pope in an attempt to combat heresy, enacted stricter anti-heresy imperial laws which included death penalty for incorrigible heretics. ${ }^{23}$ Moses Maimonides himself advocated death penalty for Jewish heretics in the same way as his Islamic counterparts. ${ }^{24}$ This is not to say that Aquinas' position on death penalty should be dismissed merely as an expression of the temperament of his time. The task of this paper after all is not to offer an apologia for Aquinas' position on capital punishment but to create an alternative way of understanding it. It is important to note that Drury's caricature of Aquinas as a bloodthirsty inquisitor ${ }^{25}$ does not at all figure in reputable and more recent literature on medieval heresies and history of

${ }^{21}$ Shadia Drury, Aquinas and Modernity: The Lost Promise of Natural Law (New York: Rowman \& Littlefield Publishers, Inc., 2008), 73.

${ }^{22}$ Shadia Drury, "Thinkers: Thomas Aquinas," in New Humanist: A quarterly journal of ideas, science and culture from the Rationalist Association (8 December 2008), <https://newhumanist.org.uk/articles/1933/thinkers-thomas-aquinas>, 8 October 2017.

${ }^{23}$ Jennifer Kolpakoff Deane, A History of Medieval Inquisition and Heresy (New York: Rowman \& Littlefield Publishers, Inc., 2011), 95.

24 Christine Caldwell Ames, Medieval Heresies: Christianity, Judaism, and Islam (Cambridge: Cambridge University Press, 2015), 216.

${ }^{25}$ Deane in fact pointed out that the notion of a medieval inquisition is pure myth and is merely a product of misrepresentation. See Deane, A History of Medieval Inquisition and Heresy, 88.

(c) 2018 Jovito V. Cariño

https://www.kritike.org/journal/issue 22/carino1 june2018.pdf

ISSN 1908-7330 


\section{AQUINAS AND CAPITAL PUNISHMENT IN THE PHILIPPINES}

inquisition like William Monter's Frontiers of Heresy (2002), Jennifer Kolpacoff Deane's A History of Medieval Heresy and Inquisition (2011), as well as Christine Caldwell Ames' Righteous Persecution: Inquisition, Dominicans, and Christianity in the Middle Ages (2009) and Medieval Heresies: Christianity, Judaism, and Islam (2015). Ames, in particular, underscored Aquinas' distinct prudential handling of the case of heretics. She made it clear that for Aquinas, inquisition was but a method of correction. Only when a heretic refused conversion after two or three attempts could the Church expel him by excommunication and turn him over to the secular tribunal to mete out the penalty of death. ${ }^{26} \mathrm{It}$ is apparent that during Aquinas' time, when it comes to heresy, capital punishment was a possibility that cannot be avoided. And because this was so, Aquinas, through writing and teaching, made sure his fellow friar preachers were equipped with requisite philosophical and theological resources to help them reach out to those who had stepped off the grid, so to speak. Thus, his painstaking effort to structure Summa Theologiae according to all conceivable questions to which a friar preacher should have a ready answer; his inclusion of his carefully-studied responses to various heretical claims throughout the ages in Book IV of Summa Contra Gentiles; ${ }^{27}$ his pious updating of the teachings of the Greek Fathers of the Church in Contra Errores Graecorum, are all part of his relentless though underrated attempt to win the hearts and minds of the so-called heretics. In the silence and modesty of his texts, Aquinas left no stone unturned to overcome the threat of the penalty of death despite its certain morbid prospect.

b) Capital punishment as a subject of legislation. We turn now to the question of murder, the second violation for which Aquinas, in Summa Theologiae is said to have recommended capital punishment. In this case, the penalty is imposed on a sinner or evildoer who has proven to be a grave threat injurious to or against the good of community. There are eight articles under Question 64 and two of these, articles 2 and 3, are linked directly with capital punishment. The Latin verb occidere is used in Question 64 to refer both to the violative act in question, i.e., murder, and the recommended penalty of death found in articles 2 and 3. The said term is applied by Aquinas in a rather generic sense and included other modes of killing like self-defense, suicide, and including the killing done by a cleric. The text of Question 64 shows clearly the high regard that Aquinas sets aside for the common good. In article 2, he compares an individual person to a part of the whole and he argues that if a certain individual "be dangerous and infectious to the community, on account of some sin, it is praiseworthy and advantageous that he be killed in order to safeguard the common good, since 'a little leaven

26 Christine Caldwell Ames, Righteous Persecution: Inquisition, Dominicans, and Christianity in the Middle Ages (Philadelphia: University of Pennsylvania Press, 2009), 200-201.

27 Thomas Aquinas, "Book IV: Salvation," in Summa Contra Gentiles.

(c) 2018 Jovito V. Cariño

https://www.kritike.org/journal/issue 22/carino1 june2018.pdf

ISSN 1908-7330

(c) $)$ BY-NC-ND 
corrupteth the whole lump' (1 Corinthians 5:6)." ${ }^{28}$ Sustaining the same argument, he once again justifies the killing of an evildoer in article 3 as long as it is directed to the good of the community but adds that only public authority, being the custodian of the common good, can lawfully act on taking the life of an erring citizen. ${ }^{29}$

Some observers detect in Aquinas' position on articles 2 and 3 a strong utilitarian and consequentialist undertone, and hence, the suggestion that he is an all-out advocate of capital punishment. His emphasis on the benefit of the community once the threat is eliminated is seen by them as an acknowledgement on his part of the advantages that a community stands to gain with the termination of the life of an individual sinner. They think that Aquinas is offering a justification for a person's death by invoking its positive effect on the community. This is the common error of those who read Question 64 along utilitarian lines. To impute, however, a utilitarian leaning on the part of Aquinas is a case not just of misreading but of grossly missing the crux of his political philosophy. The possibility of Aquinas becoming a utilitarian is as close as Aquinas abandoning his Christian faith. The divide between Thomistic ethico-political theory and utilitarianism is so sharp and wide that the chance of them ever getting remotely near to each other, much less, synchronic, is almost unimaginable. Unfortunately, advocates of capital punishment in the Philippines often mistake the contrary as true. Aquinas, unlike Bentham and the utilitarians, never considers the merit of any action according to its consequences. Ethics, for him, is more than just a question of an outcome that promotes maximum pleasure and minimum pain for the greatest number of people. Utilitarians might hail the use of atomic bombs because it brought World War II to an end, but Aquinas would not. For him, an action becomes ethics-worthy not because of its consequence, but because of the inherent consistency between the object of an action and its telos. To properly appreciate therefore Aquinas' take on capital punishment and why it should not be misidentified with utilitarianism, one needs to consider once more the main contours of Thomistic ethico-politcal theory.

Aquinas' discourse on politics borrows heavily from Aristotle, but rather than merely extend Aristotle's claims, he chose to amend his core insights and thus came up with a political theory that is patently Aristotelian and at the same time beyond Aristotle himself. It is from Aristotle that Aquinas acquires the thought of ethics and politics as conjunctive domains. As far as the Stagirite is concerned, a political community is as strong or as weak only as the citizenry that comprises it. Hence, in introducing his Nicomachean Ethics, Aristotle makes it clear that the study of ethics is

${ }^{28}$ Thomas Aquinas, Summa Theologiae, 2.2.64.2.

${ }^{29}$ Ibid., 2.2.64.3. 


\section{AQUINAS AND CAPITAL PUNISHMENT IN THE PHILIPPINES}

preparatory only for understanding what he terms as the ultimate among sciences: politics. As Aristotle explained in Book 1, Chapter 2 of Nicomachean Ethics: "Knowledge of the good would seem to be the concern of the most authoritative science, the highest master science. And this is obviously the science of politics, because it lays down which of the sciences there should be in the cities ... its end will include the ends of others and will therefore be the human good." 30 Knowledge of the ethical first principles, good practices, virtues, and norms of excellence are drilled into the individual so they can blend themselves better into the larger sphere of life in the polis. A judicious consideration therefore of Aquinas' mind on the question of capital punishment requires a preliminary recourse to his notion of law for it is in his proposed theory of law that Aquinas articulates the full political ramifications of the matter. Aquinas reserves his discussion of law in Questions 90 to 108 of the Summa Theologiae. Of particular relevance to the issue of capital punishment are Questions 90 and 91. In the former, Aquinas highlights the close link between law and common good, while in the latter, he provides distinction among various notions of law. What is evidently demonstrated in Aquinas' discussion of law in these key parts is his uncompromising commitment to moral realism. In its ordinary sense, moral realism pertains to the adherence to the objective reality of good. Unlike the modern depiction of good as a derivative either of autonomous duty as in Kant or individual sentiment as in Hume, Aquinas subscribes to a notion of good that precedes the individual's perception or determination. In the political context, such good is associated with common good. It is important to note that common good, for Aquinas, is utterly distinct from the utilitarian idea of the greatest good for the greatest number of people. Common good goes beyond the quantitative or the statistical and cannot be subjected to a public opinion poll. In Summa Theologiae, Aquinas emphasizes, more than once, the common good's rootedness in the rational structure of both the individual and the political body to which he belongs. Hence, to the question, "whether the law is always something directed to the common good?" found in Article 2 of Question 90, Aquinas responds by saying that:

... the law belongs to that which is a principle of human acts, because it is their rule and measure. Now as reason is a principle of human acts, so in reason itself there is something which is the principle in respect of all the rest ... Now the first principle in practical matters, which are the object of the practical reason, is the last

30 Aristotle, Nicomachean Ethics, trans. by Roger Crisp (Cambridge: Cambridge University Press, 2004), 4.

(c) 2018 Jovito V. Cariño

https://www.kritike.org/journal/issue 22/carino1 june2018.pdf

ISSN 1908-7330

(c) $)$ BY-NC-ND 
end: and the last end of human life is bliss or happiness ... the law must needs regard properly the relationship to universal happiness. ${ }^{31}$

In the second article of the ensuing question, Aquinas identifies this natural human proclivity towards happiness with natural law, specifically pointing out that "it is from the precepts of the natural law ... that the human reason needs to proceed ... These particular determinations, devised by human reason, are called human laws ..." On the determination of common good itself, Aquinas maintains that such responsibility and privilege belong either to the whole people or to a public personage ${ }^{32}$ although, for a more orderly dispensation, he prefers that such be carried out by a public figure rather than the populace itself. ${ }^{33}$ In Article 2 of Question 94, Aquinas demonstrates the intimate link between natural law and good, saying:

Consequently the first principle of practical reason is one founded on the notion of good, viz. that 'good is that which all things seek after.' Hence this is the first precept of law, that 'good is to be done and pursued, and evil is to be avoided.' All other precepts of the natural law are based upon this: so that whatever the practical reason naturally apprehends as man's good (or evil) belongs to the precepts of the natural law as something to be done or avoided. ${ }^{34}$

As the preceding excerpt shows, Aquinas refers to "good" not only as the welfare of an individual alone but also as the welfare of an individual belonging to a community. In one commentary, John Finnis emphasizes that, as far as Aquinas is concerned, all discussions pertaining to law are naturally political, that is, they are derived from a perception that law exists in "complete communities." 35 "Good," therefore acquires the character of common given the fact that it is shared by all in a particular society. Another element worthy of emphasis is the distinction made by Aquinas concerning "natural law" and "law of nature." In Article 2 of Question 95, for example,

31 Thomas Aquinas, Summa Theologiae, 1.2.90.2.

32 Ibid., 1.2.90.3.

${ }^{33}$ Ibid., 1.2.95.4.

${ }^{34}$ Ibid., 1.2.94.2

35 John Finnis, "Public Good: The Specifically Political Common Good in Aquinas," in Natural Law and Moral Inquiry: Ethics, Metaphysics, and Politics in the Thought of Germain Griez (Washington, D.C.: Georgetown University Press, 1998): 174-209, in Natural Law, Natural Rights and American Constitutionalism, <http://www.nlnrac.org/contemporary/new-natural-lawtheory/documents/specifically-political $>, 9$ October 2017.

(c) 2018 Jovito V. Cariño

https://www.kritike.org/journal/issue 22/carino1 june2018.pdf

ISSN 1908-7330 


\section{AQUINAS AND CAPITAL PUNISHMENT IN THE PHILIPPINES}

Aquinas differentiates the two by suggesting how the former serves as basis of the general principles of a particular law, like the law that seeks the punishment of an erring individual; the specifics, however, as to how such punishment should be carried out is something that can defined by the parameters set by the "law of nature." 36 An advocate of capital punishment therefore would be greatly disappointed if he looks into Aquinas' notion of natural law and finds nothing that can buttress his claim. In Aquinas' mind, the possibility of capital punishment is relegated to the "law of nature" which must be discerned by the prudent and the wise with utmost deliberation instead of a rubber stamp legislative body.

In Aquinas' ethico-political theory, therefore, any form of legislation has an instrumental function in relation to the pursuit of the common good and the political leader has the primary task of ensuring that such is upheld and attained. In De regno ad regem Cypri, Aquinas once more underscores the fact that "... the idea of king implies that he be one man who is chief and that he be a shepherd, seeking the common good of the multitude and not his own" ${ }^{37}$ Common good therefore, in the context of Aquinas' ethico-political theory, is at the core of the constitution and dispensation of political authority. Quite different from the modern political theories that one can find in the likes of Spinoza, Hobbes, down to Leo Strauss, Aquinas does not consider legislation as aid to the consolidation of greater state power but as tool to the achievement of the common good which by nature and by convention should be recognized as a fundamental priority. An important matter begging for determination, consistent with the exploration of this paper, is the question of whether the proposed revival of capital punishment is aimed at the promotion of common good and not as a scheme to enlarge the hegemony of the state. If it were indeed for the common good, then one would definitely find traces of attempts to approach the problems posed by the proliferation and use of illegal drugs with a maximum degree of reasonable deliberation. As of yet, none of these has come to the surface. What the public sees at the moment is the shameless display of bloodlust, public issuance of death threats, intensification of the politics of hate, and the propaganda that promises a safer environment with the institution of the culture of death. To get rid of what the current president and his men constantly refer to as "narco-politics," they have relinquished their moral ascendancy for the prospect of what I herewith describe as necro-politics. I am not sure, however, how one may justify the consistency between the common good and death as a state policy. There is always, in the extermination of life, particularly the kind undertaken by the state, that smacks of barbarism.

\footnotetext{
36 Thomas Aquinas, Summa Theologiae, 1.2.95.2.

${ }^{37}$ Thomas Aquinas, De regno ad regem Cypri, 2.13.
} 
Having rehearsed what Aquinas' mind on law, politics and common good, I do not think that such barbarism would find the least space in the general scheme of his ethico-political theory.

\section{Conclusion}

In the preceding paragraphs, I tried to put forward an argument concerning the incompatibility between the proposed re-imposition of capital punishment in the Philippines and the ethico-political theory of Thomas Aquinas. In my discussion, I showed how the invocation of Aquinas' ethical and political theories to legitimize the institution of the culture of death via the re-imposition of capital punishment in the Philippines indicates a flagrant misreading of his fundamental position concerning ethics and politics, particularly the role of legislation vis-à-vis the common good. The theological context of Aquinas' opinion on the possibility of capital punishment is likewise highlighted so as to show the nuances of his position and to illustrate how a careless disregard of such nuances could lead to a reductive reading of Aquinas' core insights. These assertions notwithstanding, I do not, in any way, purport this paper to be the last word on the debate as to whether or not capital punishment should be restored in the Philippine legal system. At the most, what it aims is to register a voice contrary to those who think that there are ethical and political merits in the revival of capital punishment and that they have the theories of Thomas Aquinas on their side. The arguments laid out in this paper show otherwise. It will do both public discourse and our collective moral compass tremendous good if more and different voices on this matter are given a hearing.

Department of Philosophy, University of Santo Tomas, Philippines

\section{References}

Ames, Christine Caldwell, Medieval Heresies: Christianity, Judaism, and Islam (Cambridge: Cambridge University Press, 2015).

Righteous Persecution: Inquisition, Dominicans, and Christianity in the Middle Ages (Philadelphia: University of Pennsylvania Press, 2009).

Aristotle, Nicomachean Ethics, trans. by Roger Crisp (Cambridge: Cambridge University Press, 2004).

Aquinas, Thomas, De Regno ad regem Cypri [On Kingship: To the King of Cyprus], trans. by Gerald B. Phelan, rev. by I. Th. Eschmann, ed. by Joseph Kenny (Torono: The Pontifical Institute of the Mediaeval Studies, 1949), in St. Thomas' Works in English, comp, by Joseph Kenny, in

(c) 2018 Jovito V. Cariño

https://www.kritike.org/journal/issue 22/carino1 june2018.pdf

ISSN 1908-7330

(cc) BY-NC-ND 


\section{AQUINAS AND CAPITAL PUNISHMENT IN THE PHILIPPINES}

Dominican House of Studies: Priory of the Immaculate Conception, $<$ http://dhspriory.org/thomas/DeRegno.htm $>, 7$ October 2017.

Summa Contra Gentiles, trans. by Anton C. Pegis, James F. Anderson, Vernon J. Bourke, and Charles J. O'Neil, ed. by Joseph Kenny (New York: Hannover House, 1955-57) in St. Thomas' Works in English, comp. by Joseph Kenny, in Dominican House of Studies: Priory of the Immaculate Conception, <http://dhspriory.org/thomas/ ContraGentiles.htm>, 7 October 2017.

Summa Theologiae, trans. by Fathers of the English Dominican Province, $2^{\text {nd }}$ and rev. ed. (London: Burns Oates \& Washbourne, Ltd., 1920), in New Advent, <http://www.newadvent.org/summa/>, 7-9 October 2017.

CNN Philippines Staff, "Overall crime rate falls in the first five months of Duterte presidency," in CNN Philippines (21 December 2016), $<\underline{\text { http://cnnphilippines.com/news/2016/12/20/Overall-crime-rate- }}$ falls-in-first-five-months-of-Duterte-presidency.html $>, 5$ October 2017.

Corrales, Nestor, "Duterte wants war on crime, drugs extended for 6 more months," in Inquirer.net (18 September 2016), <http://newsinfo. inquirer.net/816443/duterte-asks-for-another-6-months-to-stopcrime-drugs $>$, 5 October 2017.

Deane, Jennifer Kolpakoff, A History of Medieval Inquisition and Heresy (New York: Rowman \& Littlefield Publishers, Inc., 2011).

Drury, Shadia, Aquinas and Modernity: The Lost Promise of Natural Law (New York: Rowman \& Littlefield Publishers, Inc., 2008).

Terror and Civilization: Christianity, Politics and the Western Psyche (New York: Palgrave MacMillan, 2004).

"Thinkers: Thomas Aquinas," in New Humanist: A quarterly journal of ideas, science and culture from the Rationalist Association (8 December 2008), $<$ https://newhumanist.org.uk/articles/1933/thinkers -thomas-aquinas $>, 8$ October 2017.

"Duterte says he's 'happy' to eliminate drug addicts," in Philstar.com (30 September 2016), <https://www.philstar.com/other-sections/newsvideos/2016/09/30/1629004/watch-duterte-says-hes-happyeliminate-drug-addicts $>, 6$ October 2017.

Finnis, John, "Public Good: The Specifically Political Common Good in Aquinas," in Natural Law and Moral Inquiry: Ethics, Metaphysics, and Politics in the Thought of Germain Griez (Washington, D.C.: Georgetown University Press, 1998): 174-209, in Natural Law, Natural Rights and American Constitutionalism, <http://www.nlnrac.org/ contemporary/new-natural-law-theory/documents/specificallypolitical>, 9 October 2017. 
Foucault, Michel, "Society Must be Defended": Lectures at the College de France, ed. by Mauro Bertani and Alessandro Fontana, trans. by David Macey (New York: Picador, 2004).

Garland, David, The Culture of Control: Crime and Social Order in Contemporary Society (Chicago: The University of Chicago Press, 2002).

Geronimo, Jee Y., "Duterte 'normalized act of extrajudicial killing," in Rappler (06 January 2017), <https://www.rappler.com/nation/157528-duterteextrajudicial-killing-human-rights $>, 6$ October 2017.

Hegina, Aries Joseph, "Duterte: Kill me if I fail to bust crime, corruption in 6 months, in Inquirer.net (17 January 2016), $<$ http://newsinfo.inquirer.net/756194/duterte-kill-me-if-i-fail-to-bustcrime-corruption-in-6-months $>$, 5 October 2017.

Iyengar, Rishi, "The Killing Time: Inside Philippine President Rodrigo Duterte's War on Drugs," in Time (25 August 2016), $<\underline{\text { http://time.com/4462352/rodrigo-duterte-drug-war-drugs- }}$ philippines-killing/>, 5 October 2017.

“'License to Kill': Philippine Police Killings in Duterte's 'War on Drugs,'” in Human Rights Watch (March 2017), <https://www.hrw.org/sites/ default/files/report pdf/philippines0317 insert.pdf $>$, 5 June 2018.

"Philippines: Events of 2016," in Human Rights Watch, $<$ https://www.hrw.org/world-report/2017/country-chapters/ philippines\#1ff4dc $>, 5$ October 2017.

Tordesillas, Ellen T. "Opinion: Culture of death under Duterte presidency," in ABS-CBN News (04 March 2017), <http://news.abscbn.com/blogs/opinions/03/03/17/opinion-culture-of-death-underduterte-presidency> 6 October 2017. 